\title{
Clostridium difficile toxin A binding to human intestinal epithelial cells
}

\author{
J. A. SMITH, D. L. COOKE*, S. HYDE*, S. P. BORRIELLO* and R. G. LONG \\ Medical Research Centre, City Hospital, Nottingham NG5 1PB and *Institute of Infection and Immunity, \\ Queens Medical Centre, Nottingham
}

\begin{abstract}
Clostridium difficile radiolabelled toxin $\mathbf{A}\left(\left[{ }^{3} \mathrm{H}\right]\right.$-toxin $\left.\mathbf{A}\right)$ bound to human duodenal and colonic epithelial cells isolated from endoscopic biopsies. Binding was greater at $4^{\circ} \mathrm{C}$ than $37^{\circ} \mathrm{C}$, consistent with the thermal binding characteristic of toxin $A$ to a carbohydrate moiety. At $37^{\circ} \mathrm{C}$ colonic cells bound significantly more $\left[{ }^{3} \mathrm{H}\right]-$ toxin $A$ than duodenal cells. The amount of $\left[{ }^{3} \mathbf{H}\right]$-toxin $A$ binding varied considerably between individuals. $\left[{ }^{3} \mathbf{H}\right]$-toxin A was displaced by unlabelled toxin $A$ by $50 \%$ for duodenal cells and $70 \%$ for colonic cells with $94.3 \mathrm{nM}$ unlabelled toxin A. Low non-displacable binding was observed in some samples at $4^{\circ} \mathrm{C}$ and $37^{\circ} \mathrm{C}$, suggesting that these cells came from individuals incapable of specifically binding toxin. Pre-treating cells with $\alpha$ - or $\beta$ galactosidases to cleave terminal $\alpha$ - and $\beta$-galactose residues reduced $\left[{ }^{3} \mathrm{H}\right]$-toxin $A$ binding. There was also a reduction in $\left[{ }^{3} \mathbf{H}\right]$-toxin $A$ binding after heat treating cells, which is suggestive of protein binding. The reduction in binding varied between individuals. The reduction of $\left[{ }^{3} \mathrm{H}\right]$-toxin $A$ binding, after the removal of $\beta$-linked galactose units, implicates these as components of the receptor and adds credence to the idea that the Lewis $X, Y$ and $I$ antigens may be involved in toxin $A$ binding to human intestinal epithelial cells. However, because the Lewis antigens do not possess terminal $\alpha$ galactose units, the reduction in binding after $\alpha$-galactosidase treatment suggests that other receptors may be involved in toxin $A$ binding to some human intestinal cells. These data are the first demonstration of direct toxin $A$ binding to human intestinal epithelial cells.
\end{abstract}

\section{Introduction}

In the 1970s Clostridium difficile was found to be an aetiological agent of antibiotic-associated diarrhoea and pseudomembranous colitis. Intestinal infection with $C$. difficile is one of the most common causes of diarrhoea and colitis among hospitalised patients, particularly the elderly [1]. Interestingly, not all individuals colonised by toxigenic strains of $C$. difficile develop disease and human infants are not usually affected $[2,3]$.

C. difficile produces two toxins, $\mathrm{A}$ and $\mathrm{B}$, which play a role in the pathogenesis of disease [1, 4]. Animal studies have shown toxin $A$ to be an enterotoxin that elicits increased intestinal permeability, fluid secretion and inflammation and causes severe disruption of the intestinal epithelium [5-8]. It is a large, 520$540 \mathrm{kDa}$, multi-subunit protein. One of the major subunits contains repeating sequences in the $\mathrm{C}$ terminal component of the molecule which are thought

Received 13 Dec. 1996; accepted 23 March 1997.

Corresponding author: Dr R. G. Long. to be involved in toxin $\dot{\mathrm{A}}$ binding to carbohydratecontaining receptors [4].

In model systems, the carbohydrate component to which toxin A binds has been shown to contain the terminal trisaccharide sequence Gal $\alpha 1-3 \mathrm{Gal} \beta 1$ 4GlcNAc [9]. Bovine thyroglobulin [10], rabbit erythrocytes and rodent intestinal brush border membranes [9] possess this trisaccharide. It has been postulated that normal human intestinal cells do not express this sequence [11] and that the oligosaccharide blood group antigens Lewis $\mathrm{X}, \mathrm{Y}$ and $\mathrm{I}$ may be responsible for toxin $\mathrm{A}$ binding to human intestine [12].

Studies on human colonic biopsy specimens have shown that toxin A causes epithelial cell rounding, detachment and apoptosis [13]. This study also identified individuals who were not susceptible to toxin A-induced cell damage, indicating a lack of toxin A-binding receptors.

Studies of direct toxin A binding to human intestinal 
cells have not been done. In the present study, a previously described method of isolating intestinal epithelial cells from human endoscopic biopsies [14] was used to examine the binding characteristics of tritium-labelled purified toxin $A$ to duodenal and colonic epithelial cells.

\section{Materials and methods}

Coffee bean $\alpha$-galactosidase (EC 3.2.1.22) and Escherichia coli $\beta$-galactosidase (EC 3.2.1.23) were purchased from Boehringer Mannheim. The purity of these enzymes had been tested previously by Krivan et al. [9] and confirmed by us. Each preparation was free from contamination by the other enzyme. All other chemicals were from Sigma.

\section{Patients and epithelial cell isolation}

Human duodenal or colonic biopsy samples were collected from patients attending for endoscopy. Patients with suspected irritable bowel syndrome, diarrhoea, iron deficiency anaemia or colonic polyp surveillance had endoscopic biopsy samples taken as part of diagnostic investigations [14] and were asked to donate six additional samples for research purposes. No single patient had samples taken from both sites. Permission for the study was obtained from the Nottingham City Hospital Ethical Committee and patients gave informed written consent. Two further biopsy samples were taken for histological assessment and only data from patients subsequently found to have histologically normal mucosa are presented. Patients' age, sex and blood group (ABO) were recorded.

Epithelial cells were isolated from biopsy samples by a method described previously [14] with the following modifications. Biopsy samples were collected into $10 \mathrm{ml}$ of citrate buffer (pre-warmed to $37^{\circ} \mathrm{C}$ ) containing (mmol/L): $\mathrm{KCl}, 1.5 ; \mathrm{NaCl}, 96$; sodium citrate, 27; $\mathrm{KH}_{2} \mathrm{PO}_{4}, 8 ; \mathrm{Na}_{2} \mathrm{HPO}_{4}, 5.6$; and $200 \mathrm{IU}$ of penicillin and $100 \mu \mathrm{g}$ of streptomycin; (pH 7.3). After incubation for $10 \mathrm{~min}$, the citrate buffer was replaced with $10 \mathrm{ml}$ of EDTA buffer containing (mmol/L): $\mathrm{Na}_{2}-$ EDTA 1.5; dithiothreitol, $0.5 ; \mathrm{NaH}_{2} \mathrm{HPO}_{4}, 10 ; \mathrm{NaCl}$, 154; and $200 \mathrm{IU}$ of penicillin and $100 \mu \mathrm{g}$ of streptomycin (pH 7.3). The biopsy samples were then incubated for a further $30 \mathrm{~min}$ at $37^{\circ} \mathrm{C}$ with gentle agitation at intervals. The cell suspension was separated from the biopsy fragments and washed three times in HEPES-bicarbonate buffered Hanks's Balanced Salts Solution ( $\mathrm{HBH})$ containing ( $\mathrm{mmol} / \mathrm{L})$ : $\mathrm{CaCl}_{2}, 1.26 ; \mathrm{KCl}, 5.36 ; \mathrm{KH}_{2} \mathrm{PO}_{4}, 0.44 ; \mathrm{MgSO}_{4}, 0.81$; $\mathrm{NaCl}, 137 ; \mathrm{NaHCO}_{3}, 4.17 ; \mathrm{Na}_{2} \mathrm{HPO}_{4}, 0.34$; HEPES, 10 ; at $4^{\circ} \mathrm{C}$ and $\mathrm{pH} 7.4$. The $\mathrm{HBH}$ buffer was gassed with $\mathrm{CO}_{2} 5 \%, \mathrm{O}_{2} \quad 95 \%(\mathrm{v} / \mathrm{v})$. All buffers were supplemented with $5.5 \mathrm{mM}$ glucose, $2 \mathrm{mM}$ glutamine, bovine serum albumen (BSA) $2 \mathrm{mg} / \mathrm{ml}$ and soybean trypsin inhibitor $1 \mathrm{mg} / \mathrm{ml} \mathrm{[15].}$
A mean of $2.28 \times 10^{6} \mathrm{SD} 0.51 \times 10^{6}$ cells $/ \mathrm{ml}$ was isolated from six duodenal biopsy samples and a mean of $1.44 \times 10^{6} \mathrm{SD} 0.18 \times 10^{6}$ cells $/ \mathrm{ml}$ was isolated from six colonic samples; $1 \times 10^{6}$ cells were equivalent to $30 \mu \mathrm{g}$ of DNA. More than $80 \%$ of isolated cells excluded trypan blue for at least $2 \mathrm{~h}$ (86 SEM $3 \%$ immediately after isolation and 84 SEM $5 \% 2 \mathrm{~h}$ later).

\section{C. difficile toxin A purification and radiolabelling}

Highly purified toxin A was used for this study as described previously $[10,16]$. C. difficile strain VPI 10463 was used for toxin production. Briefly, separation and purification of toxin A from toxin B was by thermal elution of $C$. difficile culture filtrate from a bovine thyroglobulin affinity column. Further purification of toxin A was by anion-exchange gel-Q Sepharose FF (Pharmacia) followed by Mono Q (Pharmacia) incorporated into a fast protein liquid chromatography apparatus (Pharmacia) [17].

Toxin A was $\left[{ }^{3} \mathrm{H}\right]$-labelled with $\mathrm{N}$-succinimidyl[2,3${ }^{3} \mathrm{H}$ ] propionate (Bolton-Hunter reagent) as described by Pothoulakis et al. [18]. As found by others, no loss of cytotoxicity was exhibited by $\left[{ }^{3} \mathrm{H}\right]$-toxin $\mathrm{A}$ when compared to unlabelled toxin $A$ tested in cultured Vero cells and $\mathrm{Caco} 2$ cells $[10,13,18]$. Binding of toxin $A$ to bovine thyroglobulin [10] and haemagglutination of rabbit erythrocytes [9] were also unaffected by radiolabelling.

\section{$\left[{ }^{3} \mathrm{H}\right]$-toxin $\mathrm{A}$ binding to isolated duodenal and colonic epithelial cells}

Displacement curves were constructed by incubating isolated intestinal epithelial cells $(200 \mu \mathrm{l})$ with $100 \mu \mathrm{l}$ of $\left[{ }^{3} \mathrm{H}\right]$-toxin A (65 ng $\left.\equiv 1.2 \mathrm{nM} \equiv 87598 \mathrm{dpm}\right)$ and $100 \mu \mathrm{l}$ of increasing concentrations of unlabelled toxin A over the range $0-50 \mu \mathrm{g} / \mathrm{ml}$ at $4^{\circ} \mathrm{C}$ and $37^{\circ} \mathrm{C}$. Incubations were for $60 \mathrm{~min}$ because preliminary time course experiments showed that $\left[{ }^{3} \mathrm{H}\right]$-toxin A binding was maximal by this time.

Bound $\left[{ }^{3} \mathrm{H}\right]$-toxin A was separated from free toxin A by rapid filtration through glass fibre filters $(25 \mathrm{~mm})$ pre-wetted with $50 \mathrm{mM}$ Tris-BSA 1\%, pH 7.5 (T-BSA) mounted on a filtration manifold connected to a vacuum pump. Filters were washed with three 3-ml volumes of ice-cold T-BSA and liquid scintillation counted. Non-specific binding (NSB) to filters was $<2 \%$ of total radioactivity added. The amount of radioactivity bound to cells was calculated by subtracting NSB and expressed as dpm $/ \mu \mathrm{g}$ of DNA or as a percentage of $\left[{ }^{3} \mathrm{H}\right]$-toxin $A$ bound in the absence of unlabelled toxin $\mathrm{A}$.

The importance of carbohydrate (galactose residues) and protein to the binding of toxin $A$ to human intestinal cells was investigated. The carbohydrate 
dependency of $\left[{ }^{3} \mathrm{H}\right]$-toxin $A$ binding was tested by pre-treating cells with $\alpha$ - or $\beta$-galactosidases [16]. These enzymes cleave terminal $\alpha$ - and $\beta$-galactose residues found in the known toxin $\mathrm{A}$ binding sequence Gal $\alpha 1-3 \mathrm{Gal} \beta 1-4 \mathrm{GlcNAc}$ and the Lewis $\mathrm{X}, \mathrm{Y}$ and I antigens $[9,12,19] ; \alpha$ - or $\beta$-galactosidase $(1.5 \mathrm{U})$ was incubated with $200 \mu \mathrm{l}$ of cells for $1 \mathrm{~h}$ at $22^{\circ} \mathrm{C}$. The protein dependency of toxin $\mathrm{A}$ binding was tested by heating cells for $10 \mathrm{~min}$ at $100^{\circ} \mathrm{C}$. The ability of pretreated cells to bind toxin $\mathrm{A}$ was then tested by incubating cells at $4^{\circ} \mathrm{C}$ for $1 \mathrm{~h}$ in the presence of $100 \mu 1$ of $\left[{ }^{3} \mathrm{H}\right]$-toxin $\mathrm{A}$. Cell-bound $\left[{ }^{3} \mathrm{H}\right]$-toxin $\mathrm{A}$ was separated from free toxin as described above.

\section{Statistical analysis}

Data were analysed by the StatView $512+$ statistics software package. Mean radioactivity counts were compared by Student's $t$ test.

\section{Results}

Greater toxin $\mathrm{A}$ binding was observed at $4^{\circ} \mathrm{C}$ than at $37^{\circ} \mathrm{C}$ in both duodenal $(\mathrm{p}=0.05)$ and colonic $(p=0.02)$ isolated epithelial cells. This is consistent

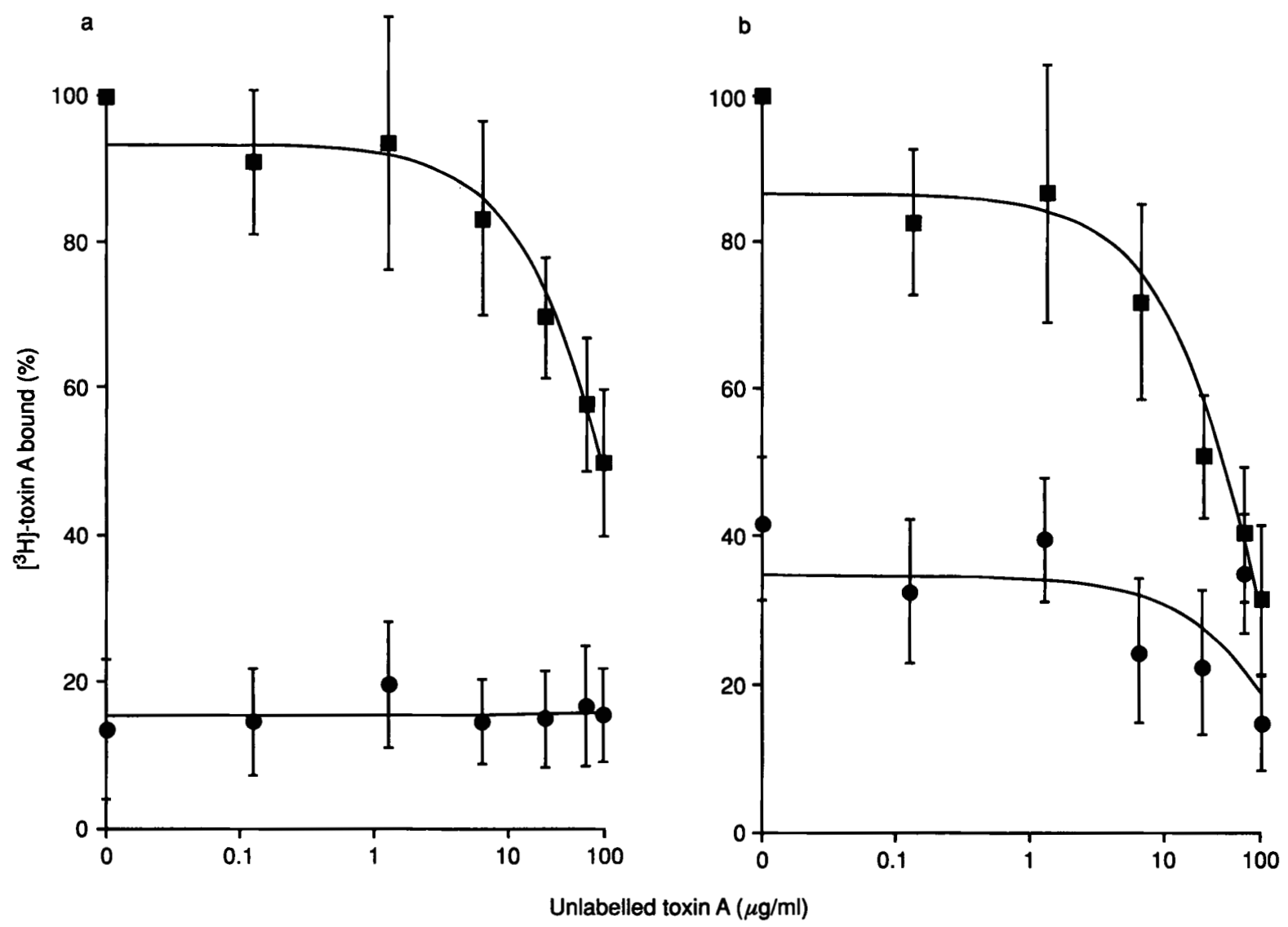

Fig. 1. Displacement of $\left[{ }^{3} \mathrm{H}\right]$-toxin A binding to isolated human duodenal (a) and colonic (b) epithelial cells at $4^{\circ} \mathrm{C}(\boldsymbol{\square})$ and $37^{\circ} \mathrm{C}(\Theta)$ after incubation for $1 \mathrm{~h}$. $\left[{ }^{3} \mathrm{H}\right]$-toxin A was displaced by unlabelled toxin A by $c .50 \%$ and $70 \%$, respectively, for duodenal $(n=5)$ and colonic $(n=6)$ cells at the maximum concentration of unlabelled toxin $A$ tested $(50 \mu \mathrm{g} / \mathrm{ml}=94.3 \mathrm{nM})$. Data are expressed as percentage of $\left[{ }^{3} \mathrm{H}\right]$-toxin $\mathrm{A}$ bound where maximum binding at $4^{\circ} \mathrm{C}$ in the absence of any unlabelled toxin $A$ was taken to be $100 \%$ for experiments at $4^{\circ} \mathrm{C}$ and $37^{\circ} \mathrm{C}$. with the known thermal binding characteristic of toxin A to a carbohydrate moiety. At $4^{\circ} \mathrm{C}$, duodenal and colonic epithelial cells bound similar amounts of $\left[{ }^{3} \mathrm{H}\right]-$ toxin A. However, at $37^{\circ} \mathrm{C}$ (i.e., physiological temperathan duodenal cells $(p=0.02)$. The amount of $\left[{ }^{3} \mathrm{H}\right]-$ toxin A binding to intestinal cells from different individuals varied considerably (Table 1). The amount of $\left[{ }^{3} \mathrm{H}\right]$-toxin A binding did not correlate with patient age, sex or blood group.

$\left[{ }^{3} \mathrm{H}\right]$-toxin A displacement curves (Fig. 1) constructed for epithelial cells isolated from duodenal and colonic biopsy samples showed that $\left[{ }^{3} \mathrm{H}\right]$-toxin $A$ was

Table 1. $\left[{ }^{3} \mathrm{H}\right]$-Toxin A binding to isolated human intestinal epithelial cells at $4^{\circ} \mathrm{C}$ and $37^{\circ} \mathrm{C}$ after incubation for $1 \mathrm{~h}$

\begin{tabular}{lcc}
\hline & \multicolumn{2}{c}{ Mean (and SEM) dpm $/ \mu \mathrm{g}$ of DNA (range) } \\
\cline { 2 - 3 } Temperature & Duodenum $(\mathrm{n}=9)$ & Colon $(\mathrm{n}=10)$ \\
\hline $4^{\circ} \mathrm{C}$ & 421.79 SEM 136.01 & 439.29 SEM 131.56 \\
& $(61.80-1254.81)$ & $(68.90-1248.74)$ \\
$37^{\circ} \mathrm{C}$ & 50.61 SEM 26.75 & 188.38 SEM 75.20 \\
& $(12.48-154.85)$ & $(17.40-814.35)$ \\
\hline
\end{tabular}
ture), colonic cells bound significantly more toxin A 
displaced by unlabelled toxin A by c. $50 \%$ and $70 \%$, respectively, at $4^{\circ} \mathrm{C}$ at the maximum concentration of unlabelled toxin A tested $(50 \mu \mathrm{g} / \mathrm{ml}=94.3 \mathrm{nM})$. This was the maximum concentration available and was a 314-fold excess over the final labelled $\left[{ }^{3} \mathrm{H}\right]$-toxin A concentration $(0.3 \mathrm{nM})$. There was little displacement at $37^{\circ} \mathrm{C}$. The displacement of $\left[{ }^{3} \mathrm{H}\right]$-toxin A was more pronounced with colonic cells than duodenal cells.

Of the nine duodenal and 10 colonic samples tested, unlabelled toxin $\mathrm{A}$ was unable to displace labelled $\left[{ }^{3} \mathrm{H}\right]$-toxin A from four duodenal and four colonic samples, suggesting that binding to these cells was non-specific. However, increased binding at $4^{\circ} \mathrm{C}$ compared to $37^{\circ} \mathrm{C}$ was still observed in these cell preparations (Fig. 2).

The effectiveness of reducing $\left[{ }^{3} \mathrm{H}\right]$-toxin A binding by pre-treating cells with $\alpha$-galactosidase varied considerably between individuals. Cleavage of terminal $\alpha$ galactose residues had no effect on $\left[{ }^{3} \mathrm{H}\right]$-toxin $\mathrm{A}$ binding to cells from three of the seven duodenal samples and reduced binding by $3 \%, 8 \%, 37 \%$ and $49 \%$ in the other four. In contrast, binding to all the colonic samples tested was reduced by an average of $80 \%$ (range $18-100 \%$ ). Table 2 compares data from

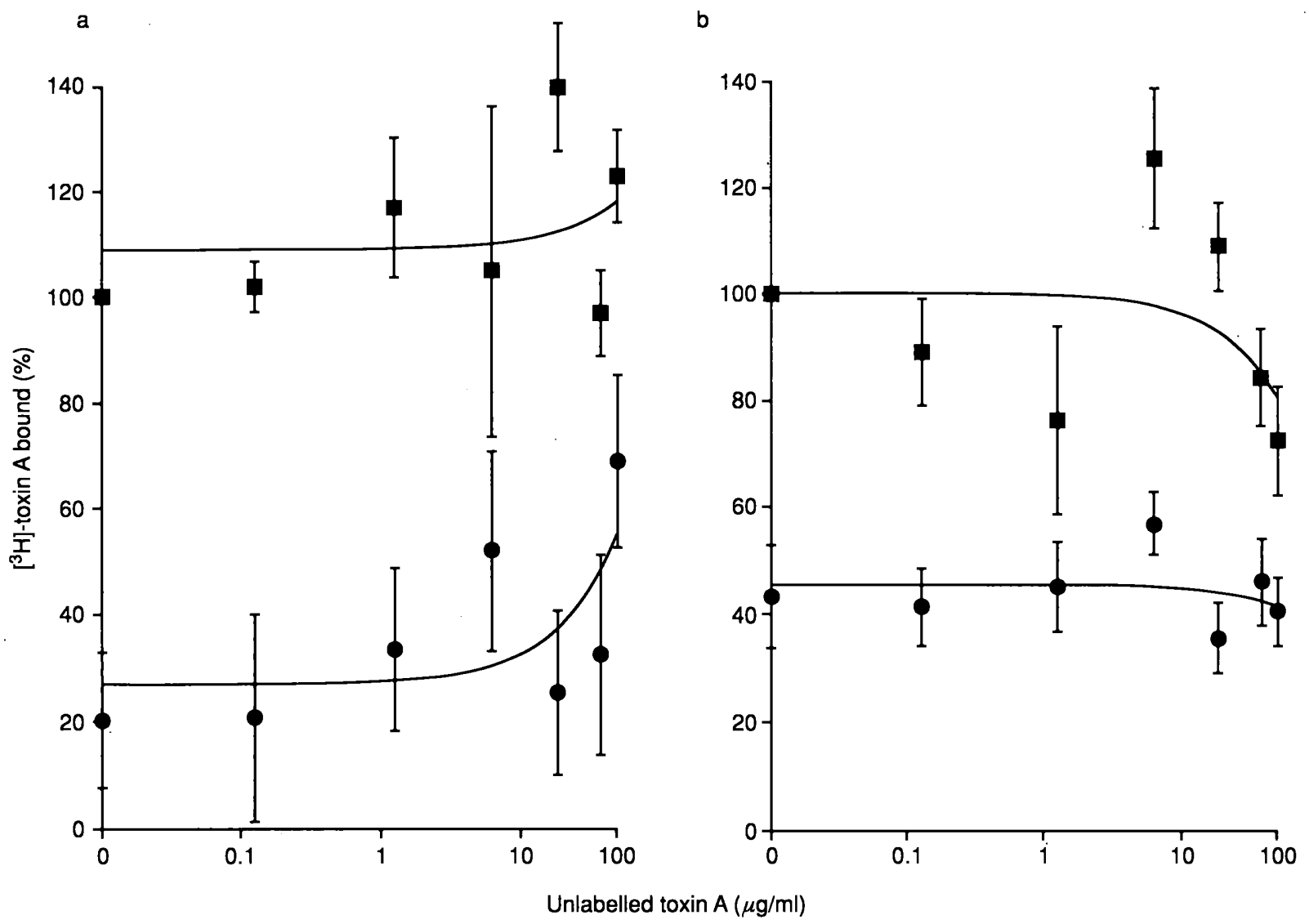

Fig. 2. $\left[{ }^{3} \mathrm{H}\right]$-toxin A displacement curves for isolated human duodenal (a) and colonic (b) epithelial cells at $4^{\circ} \mathrm{C}$ ( $\square$ ) and $37^{\circ} \mathrm{C}(0)$ after incubation for $1 \mathrm{~h}$. Unlabelled toxin A was unable to displace $\left[{ }^{3} \mathrm{H}\right]$-toxin $A$ in four duodenal and four colonic cell samples over the unlabelled toxin $A$ concentration range of $0.125-50 \mu \mathrm{g} / \mathrm{ml}$. Data are expressed as percentage $\left[{ }^{3} \mathrm{H}\right]$-toxin $\mathrm{A}$ bound where maximum binding at $4^{\circ} \mathrm{C}$ in the absence of any unlabelled toxin $\mathrm{A}$ was taken as $100 \%$ for experiments at $4^{\circ} \mathrm{C}$ and $37^{\circ} \mathrm{C}$.
Table 2. $\left[{ }^{3} \mathrm{H}\right]$-toxin A binding to isolated human intestinal epithelial cells after pre-treatment with $\alpha$ - or $\beta$ galactosidases or heat compared to untreated cells

Each datum point is the mean of duplicate determinations from cells isolated from duodenal or colonic biopsy samples.

${ }^{*}$ Cells in which all three parameters were important for toxin A binding.

Cells in which terminal $\beta$-galactose residues were important for toxin A binding.

$\ddagger$ Cells in which toxin $\mathrm{A}$ binding was completely carbohydrate dependent. Heat treatment had no effect on toxin A binding.

cell preparations pre-treated with $\alpha$ - or $\beta$-galactosidase or heated. The significance of $\alpha$ - or $\beta$-galactose residues and the proportion of toxin A binding that was dependent on heat-stable protein was different for each individual tested. For all but one sample, an

\begin{tabular}{lccc}
\hline \multirow{2}{*}{ Site } & \multicolumn{3}{c}{$\left[{ }^{3} \mathrm{H}\right]$-toxin $\mathrm{A}$ bound (\%) following pre-treatment with } \\
\cline { 2 - 4 } & Heat $\left(100^{\circ} \mathrm{C}\right)$ & $\alpha$-galactosidase & $\beta$-galactosidase \\
\hline Duodenum & 47 & 51 & $45^{*}$ \\
& 59 & 100 & $0 \dagger$ \\
& 56 & 29 & $34^{*}$ \\
Colon & 70 & 32 & $12^{*}$ \\
& 39 & 37 & $0 \dagger$ \\
& 100 & 0 & $0 \ddagger$ \\
& 14 & 17 & $18^{*}$ \\
& 1 & 29 & $34^{*}$ \\
\hline
\end{tabular}


element of protein-dependent binding was present in all the cell preparations tested.

\section{Discussion}

Isolated human intestinal cells bound $C$. difficile toxin A. Binding was greater at $4^{\circ} \mathrm{C}$ that at $37^{\circ} \mathrm{C}$. Greater binding at $4^{\circ} \mathrm{C}$ is a characteristic of toxin $\mathrm{A}$ [12] and is indicative of cold agglutination where increased cell surface receptor density at $4^{\circ} \mathrm{C}$ enhances binding of large multivalent proteins to carbohydrate receptors [20]. Toxin A is such a protein, with several repeating epitopes that facilitate multiple binding interactions between the toxin and its receptor [21]. Receptor mediated endocytosis (RME) is thought to be involved in toxin A internalisation and cellular intoxication [21]. Under normal circumstances, when a hormone-receptor complex is internalised, it is processed and the receptor is returned to the cell surface [22]. At $4^{\circ} \mathrm{C} R M E$ is arrested and toxin $\mathrm{A}$ binding receptors remain on the cell surface. The lower toxin $A$ binding at $37^{\circ} \mathrm{C}$ also suggests that toxin A-bound receptors may not be returned to the cell surface.

In man, the colon is the main site of $C$. difficile infection but there are reports that $C$. difficile has been isolated from the human small bowel [23] and can cause small bowel disease $[24,25]$. To our knowledge, this study is the first to demonstrate that toxin A can bind to human small intestinal epithelial cells. Colonic cells bound significantly more $\left[{ }^{3} \mathrm{H}\right]$-toxin $A$ than duodenal cells at $37^{\circ} \mathrm{C}$. This finding is indicative of a greater number of toxin $\mathrm{A}$ receptors in the colon than in the duodenum. An alternative explanation is that preparations of duodenal cells, which have been disorganised, permit brush border enzymes, such as $\beta$ galactosidase (lactase E.C. 3.2.1.108), access to brush border carbohydrate receptors, and thereby reduce the number of functional receptors that may be present. This would not be the case for colonic tissue.

The results of this study demonstrate several significant differences in the binding characteristics of $C$. difficile toxin A to intestinal epithelial cells from the human population compared to those demonstrated in laboratory animals.

First, human gut cells pre-treated with $\alpha$ - or $\beta$ galactosidase or heat denatured membrane receptors, revealed variation between individuals in the carbohydrate and possibly the protein component of receptors involved in binding toxin $\mathrm{A}$. In contrast, Pathoulakis et al. [26] demonstrated a single class of membrane receptors, identified as Galal-3Gal $\beta 1$ 4GlcNAc (with an apparent dissociation constant of $54 \mathrm{nM}$ ), thought to be coupled to sucrase-isomaltase in New Zealand rabbit ileal brush border membranes. It is unlikely that toxin A binds to a single receptor in the human intestinal mucosa, given the variation in the binding characteristics observed between individuals in this study. Therefore, it was considered inappropriate to calculate affinity constants from the displacement data. Cell-specific displacable binding was observed predominantly at $4^{\circ} \mathrm{C}$. The low non-displaceable binding observed in some samples at $4^{\circ} \mathrm{C}$ and $37^{\circ} \mathrm{C}$ suggests that these cells came from individuals incapable of specific binding of toxin A. At a physiological temperature specific receptor binding is greatly reduced and non-specific cell binding predominates. The pathological significance of this nonspecific binding to cells is unknown. However, it may have relevance to disease because lack of the receptor binding repeating sequence of the toxin A molecule, or lack of the cellular carbohydrate receptor, did not completely abolish the cytotoxic effects of toxin A on cultured cells [21, 27, 28].

Secondly, the removal of terminal $\beta$-galactose residues by $\beta$-galactosidase reduced $\left[{ }^{3} \mathrm{H}\right]$-toxin binding to human intestinal epithelial cells. However, similar experiments have shown that $\left[{ }^{3} \mathrm{H}\right]$-toxin $A$ binding was increased in rabbit ileal brush border membranes [18] and had no effect on binding to hamster brush border membranes or rabbit erythrocytes [9]. This latter finding is of interest because it suggests that Escherichia coli $\beta$-galactosidase is incapable of cleaving $\beta$-linked galactose of the known toxin A binding trisaccharide sequence $\mathrm{Gal} \alpha 1-3 \mathrm{Gal} \beta 1$ 4GlcNAc in these tissues. The reduction of $\left[{ }^{3} \mathrm{H}\right]$-toxin A binding to human gut cells, after the removal of $\beta$ linked galactose units, adds credence to the idea that the carbohydrates of the Lewis $\mathrm{X}$ antigen system may be involved in toxin A binding to human intestinal epithelial cells (Table 2). Similarly, because the Lewis antigens do not possess terminal $\alpha$-galactose units, the reduction in binding after $\alpha$-galactosidase treatment suggests that $\mathrm{Gal} \alpha 1-3 \mathrm{Gal} \beta 1-4 \mathrm{GlcNAc}$ may also be involved in toxin A binding to some human intestinal cells. These findings do not concur with those of Galili et al. [11] who showed that Gal $\alpha 1-3 \mathrm{Gal} \beta 1$ 4GlcNAc was not present on the cells of man, apes and old world monkeys. This discrepancy needs further investigation. In contrast to our findings, heat treatment of hamster brush border membranes did not reduce toxin $\mathrm{A}$ binding and it was concluded that binding in hamster tissue was predominantly carbohydrate dependent [9].

Cell surface carbohydrates may be protein- or lipidlinked and they exhibit diverse structural polymorphisms that are tissue specific [29]. Protein glycosylation is important for post-translational protein folding and migration and most proteins expressed at the cell surface are glycosylated [30]. Therefore, the specificity of toxin A binding will be dependent not only on the carbohydrate component but also on the conjugate to which it is attached. Individual variation in a 'wild' population is inevitable and likely to account for differences in disease susceptibility. Therefore, further 
clinically relevant studies on human intestinal epithelial cells are required to correlate disease susceptibility with toxin A binding characteristics.

This work was funded by the Trent Regional Health Authority and a Medical Research Council Programme Grant (no. G9122850).

\section{References}

1. Borriello SP. Pathogenesis of Clostridium difficile infection of the gut. J Med Microbiol 1990; 33: 207-215.

2. Johnson S, Clabots CR, Linn FV, Olson MM, Peterson LR, Gerding DN. Nosocomial Clostridium difficile colonisation and disease. Lancet 1990; 336: 97-100.

3. Viscidi R, Willey S, Bartlett JG. Isolation rates and toxigenic potential of Clostridium difficile isolates from various patient populations. Gastroenterology 1981; 81: 5-9.

4. Fiorentini C, Thelestam M. Clostridium difficile toxin A and its effects on cells. Toxicon 1991; 29: 543-567.

5. Burakoff $\mathrm{R}$, Zhao L, Celifarco AJ et al. Effects of purified Clostridium difficile toxin A on rabbit distal colon. Gastroenterology 1995; 109: 348-354.

6. Castex F, Jouvert S, Bastide M, Corthier G. Kinetics of appearance of intestinal lesions in mice mono-associated with a lethal or non-lethal strain of Clostridium difficile. $J$ Med Microbiol 1994; 40: 102-109.

7. Eglow R, Pothoulakis C, Itzkowitz S et al. Diminished Clostridium difficile toxin A sensitivity in newborn rabbit ileum is associated with decreased toxin A receptor. $J$ Clin Invest 1992; 90: 822-829.

8. Torres J, Jennische E, Lange S, Lönnroth I. Enterotoxin from Clostridium difficile; diarrhoeogenic potency and morphological effects in the rat intestine. Gut 1990; 31: 781-785.

9. Krivan HC, Clark GF, Smith DF, Wilkins TD. Cell surface binding site for Clostridium difficile enterotoxin: evidence for a glycoconjugate containing the sequence Gal $\alpha 1-3 \mathrm{Gal} \beta 1$ 4GlcNAc. Infect Immun 1986; 53: 573-581.

10.' Kamiya S, Reed PJ, Borriello SP. Purification and characterisation of Clostridium difficile toxin $\mathrm{A}$ by bovine thyroglobulin affinity chromatography and dissociation in denaturing conditions with and without reduction. J Med Microbiol 1989; 30: 69-77.

11. Galili U, Shohet SB, Kobrin E, Stults CLM, Macher BA. Man, apes, and old world monkeys differ from other mammals in the expression of $\alpha$-galactosyl epitopes on nucleated cells. $J$ Biol Chem 1988; 263: 17755-17762.

12. Tucker KD, Wilkins TD. Toxin A of Clostridium difficile binds to the human carbohydrate antigens $\mathrm{I}, \mathrm{X}$, and $\mathrm{Y}$. Infect Immun 1991; 59: 73-78.

13. Mahida YR, Makh S, Hyde S, Gray T, Borriello SP. Effect of Clostridium difficile toxin $\mathrm{A}$ on human intestinal epithelial cells: induction of interleukin 8 production and apoptosis after cell detachment. Gut 1996; 38: 337-347.

14. Smith JA, Griffin M, Mireylees SE, Long RG. Effect of vasoactive intestinal peptide on cyclic adenosine monophos- phate production in enterocytes isolated from human duodenal biopsy specimens. Gut 1990; 31: 1350-1354.

15. Pinkus LM, Sulimovivi S, Susser FI, Roginsky MS. Involvement of calmodulin in the regulation of adenylate cyclase activity in guinea-pig enterocytes. Biochim Biophys Acta 1983; 762: $552-559$.

16. Kamiya S, Borriello SP. A non-haemagglutinating form of Clostridium difficile toxin A. J Med Microbiol 1992; 36: 190-197.

17. Borriello SP, Barclay FE, Reed PJ, Welsh AR, Brown JD, Burdon DW. Analysis of latex agglutination test for Clostridium difficile toxin $\mathrm{A}$ (D-1) and differentiation between $C$. difficile toxins $\mathrm{A}$ and $\mathrm{B}$ and latex reactive protein. $J$ Clin Pathol 1987; 40: 573-580.

18. Pothoulakis C, LaMont JT, Eglow $R$ et al. Characterization of rabbit ileal receptors for Clostridium difficile toxin A. Evidence for a receptor-coupled $\mathrm{G}$ protein. $J$ Clin Invest 1991; 88: 119-125.

19. Li Y-T, Li S-C. Use of enzymes in elucidation of structure. In: Horowitz MI, Pigman W (eds) The glycoconjugates, vol 1. New York, Academic Press. 1977: 51-67.

20. Tsai C-M, Zopf DA, Ginsburg V. The molecular basis for cold agglutination: effect of receptor density upon thermal amplitude of a cold agglutinin. Biochem Biophys Res Commun 1978; 80: 905-910.

21. von Eichel-Streiber C, Boquet P, Sauerborn M, Thelestam M. Large clostridial cytotoxins - a family of glycosyltransferases modifying small GTP-binding proteins. Trends Microbiol 1996; 4: $375-382$.

22. Schwartz AL. Receptor cell biology: receptor-mediated endocytosis. Pediatr Res 1995; 38: 835-843.

23. Taylor RH, Borriello SP, Taylor AJ. Isolation of Clostridium difficile from the small bowel. $B M J$ 1981; 283: 412.

24. Testore GP, Nardi F, Babudieri S, Giuliano M, Di Rosa R, Panichi G. Isolation of Clostridium difficile from human jejunum: identification of a reservoir for disease? $J$ Clin Pathol 1986; 39: 861-862.

25. Tsutaoka B, Hansen J, Johnson D, Holodniy M. Antibioticassociated pseudomembranous enteritis due to Clostridium difficile. Clin Infect Dis 1994; 18: 982-984.

26. Pothoulakis C, Gilbert RJ, Cladaras C et al. Rabbit sucraseisomaltase contains a functional intestinal receptor for Clostridium difficile toxin A. J Clin Invest 1996; 98: 641-649.

27. von-Eichel-Streiber C, Sauerborn M, Kuramitsu HK. Evidence for a modular structure of the homologous repetitive $\mathrm{C}$ terminal carbohydrate-binding sites of Clostridium difficile toxins and Streptococcus mutans glucosyltransferases. $J$ Bacteriol 1992; 174: 6707-6710.

28. Tucker KD, Carrig PE, Wilkins TD. Toxin A of Clostridium difficile is a potent cytotoxin. J Clin Microbiol 1990; 28: 869871.

29. Holgersson J, Breimer ME, Samuelssòn BE. Basic biochemistry of cell-surface carbohydrates and aspects of the tissue distribution of histoblood group $\mathrm{ABH}$ and related glycolipids. APMIS 1992; 100(S27): 18-27.

30. Gahmberg CG, Tolvanen $M$. Why mammalian cell surface proteins are glycoproteins. Trends Biochem Sci 1996; 21: 308-311. 